\section{Cureus}

\title{
A Rare Case of a Benign Primary Pleomorphic Adenoma of the Lung
}

\author{
Venkatkiran Kanchustambham $^{1}$, Swetha Saladi ${ }^{2}$, Setu Patolia ${ }^{2}$, Sara Mahmoud Assaf ${ }^{3}$, \\ David Stoeckel ${ }^{2}$
}

1. Pulmonary and Critical Care, Sanford Health Care, University of North Dakota 2. Pulmonary and Critical Care Medicine, Saint Louis University School of Medicine 3. Internal Medicine, Saint Louis University School of Medicine

$\square$ Corresponding author: Venkatkiran Kanchustambham, vkanchus81@gmail.com Disclosures can be found in Additional Information at the end of the article

\section{Abstract}

Salivary gland tumors (SGT) constitute a small proportion of primary respiratory system neoplasms. Benign SGT comprises pleomorphic adenoma and is exceedingly rare in the lungs. We hereby present a rare case of a benign primary pleomorphic adenoma of the lung. The histological pattern of the tumor was indistinguishable from the head and neck SGT counterparts and showed biphasic morphology. Malignant features were not observed and a metastatic SGT was ruled out. Although little is known about the clinical progression of these rare tumors, surgical resection and interval surveillance remains the treatment of choice.

Categories: Internal Medicine, Oncology, Pulmonology

Keywords: pleomorphic adenoma, lung tumors, salivary gland tumour

\section{Introduction}

Pleomorphic adenomas (PA) are the most common type of salivary gland tumors. Histologically, they are characterized by mixed epithelial, myoepithelial and stromal cell components. PA can occasionally undergo a malignant transformation to a carcinoma ex-pleomorphic adenoma and give rise to metastasis. Rarely, they can arise in the tracheobronchial system as primary neoplasm [1]. Pulmonary salivary gland tumors have been the subject of isolated case reports. Herein, we describe a case of an incidental finding of a lung PA in a patient initially admitted for diabetic ketoacidosis. Informed consent was obtained from the patient for this study.

\section{Case Presentation}

Received 01/27/2017 Review began 01/28/2017 Review ended 02/24/2017 Published 03/02/2017

\section{C) Copyright 2017}

Kanchustambham et al. This is an open access article distributed under the terms of the Creative Commons Attribution License CCBY 3.0., which permits unrestricted use, distribution, and reproduction in any medium, provided the original author and source are credited.
A 63-year-old African American female was admitted to our hospital with nausea, vomiting and abdominal pain of few days duration. She was diagnosed with diabetic ketoacidosis and was started on an insulin drip. Her continuous abdominal pain warranted a computed tomography (CT) of the abdomen and pelvis which revealed an incidental finding of a $3.3 \times 2.7 \mathrm{~cm}$ left lower lobe pulmonary mass, potentially representing a malignant neoplasm. In retrospect, our patient denied any a cough, shortness of breath, hemoptysis or weight loss. A subsequent chest CT scan showed a soft tissue attenuating mass in the medial left lower lobe measuring $3.5 \times 4.1$ x $3.1 \mathrm{~cm}$ (Figure 1). A diagnostic bronchoscopy revealed a big left lower lobe mass.

Endobronchial ultrasound (EBUS) guided fine needle aspiration (FNA) biopsy of the mass was obtained. A histological examination demonstrated benign bronchial and ductal epithelial cells intermingled with a myxoid mesenchymal matrix, stromal cells, and cartilage (Figures 2-3). No malignant features were identified and diagnosis of benign PA of the lung was subsequently made. After that, a physical examination of the salivary gland was conducted to exclude a 


\section{Cureus}

metastatic nature of the lung neoplasm and it was normal. The patient was discharged from the hospital with instructions to follow-up with the pulmonary clinic in two weeks.

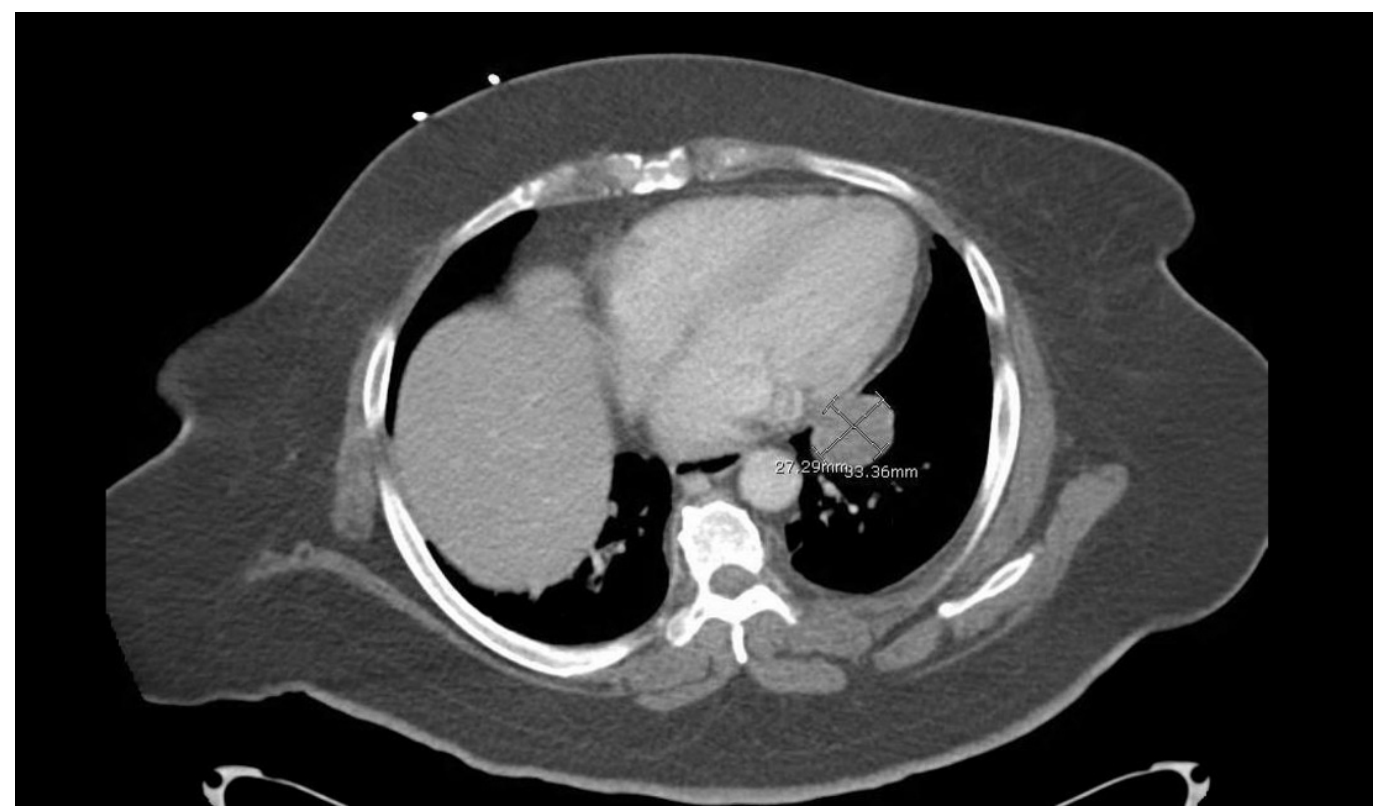

FIGURE 1: The CT scan of the chest showing a soft tissue attenuating mass in the medial left lower lobe measuring $3.5 \mathrm{x}$ $4.1 \times 3.1 \mathrm{~cm}$

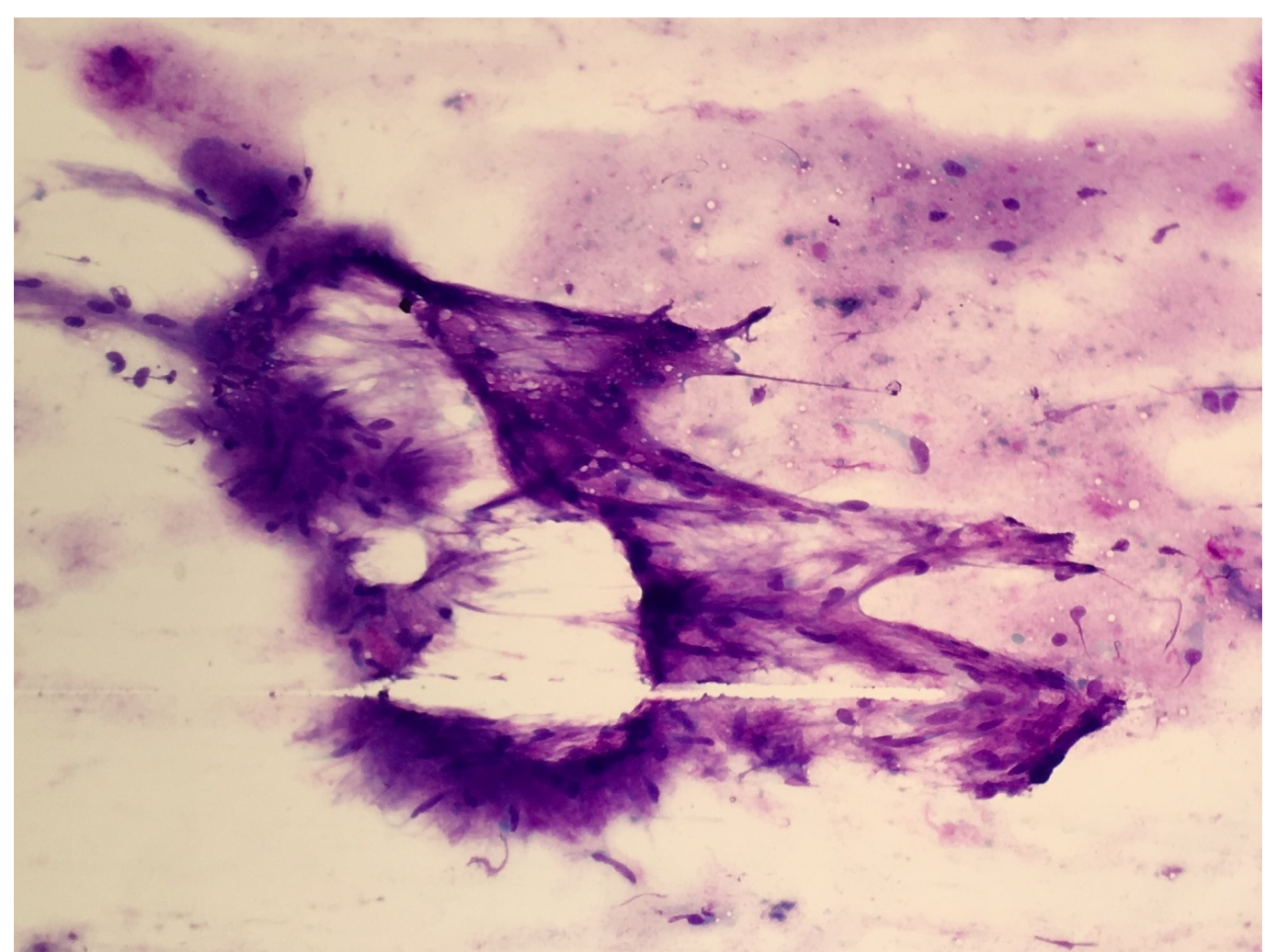

FIGURE 2: Papanicolaou stained slides showing lymphocytes, benign bronchial and ductal epithelial cells, a myxoid 


\section{Cureus}

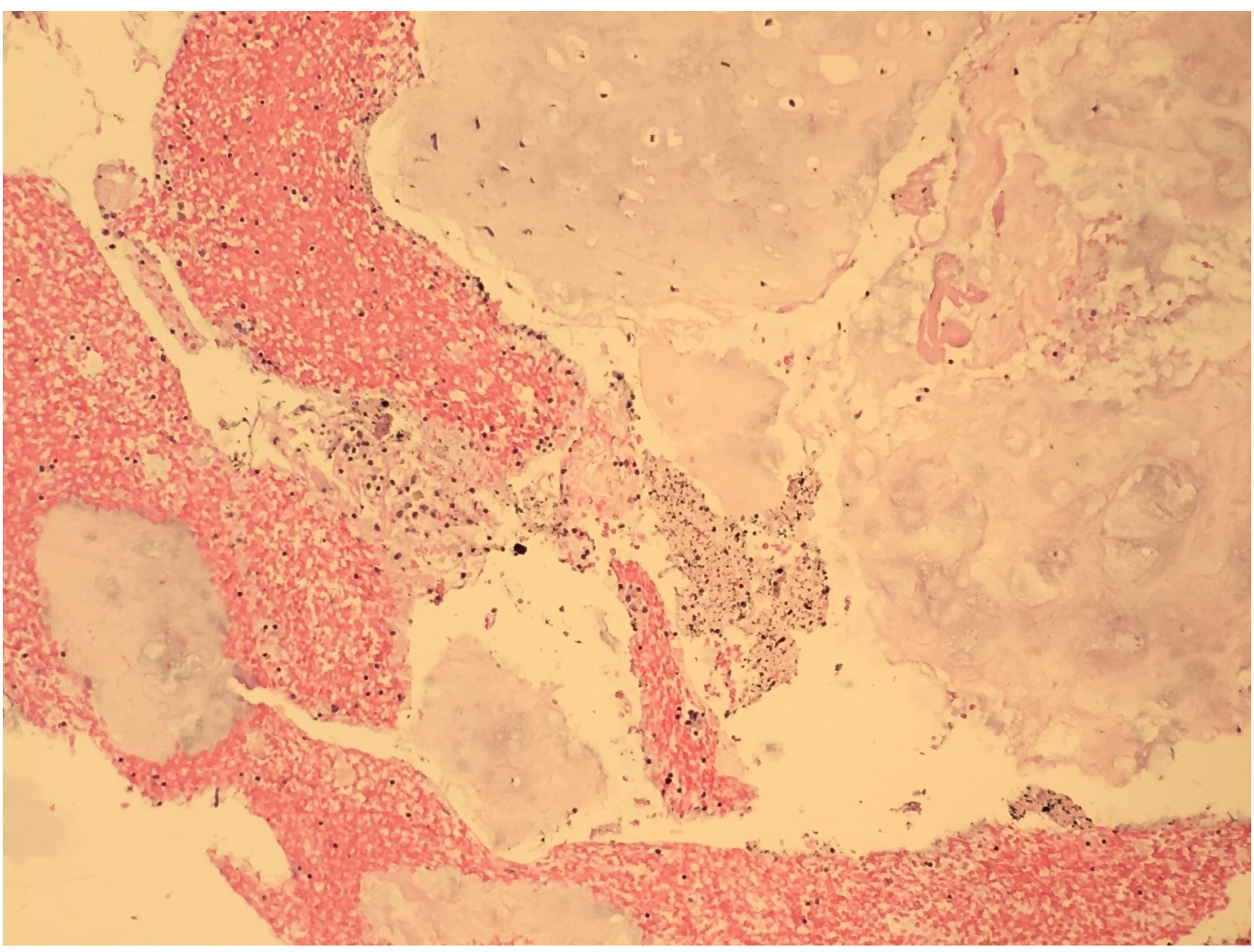

FIGURE 3: Cell block showing blood, cartilage and rare groups of small uniform epithelial cells

\section{Discussion}

Pulmonary salivary gland tumors are extremely rare and account for < one percent of all lung neoplasms. A review of the literature, summarized in table 1 , showed isolated cases of benign primary lung PA [2-9]. 


\section{Cureus}

\begin{tabular}{|c|c|c|c|c|c|}
\hline Age/Sex & Location & Size & Clinical presentation & Management & Reference \\
\hline 47/temale & $\begin{array}{l}\text { Left mainstem } \\
\text { bronchus }\end{array}$ & $\begin{array}{l}2.5 \\
\mathrm{~cm}\end{array}$ & Cough, chest pain & Pneumonectomy & $\begin{array}{l}\text { Moran, et al. } \\
2006\end{array}$ \\
\hline 45/female & Lett lower lobe & $\begin{array}{l}2.5 \\
\mathrm{~cm}\end{array}$ & Incidental finding & Lobectomy & Moran, et al.2006 \\
\hline 42/temale & Right lower lobe & $\begin{array}{l}2.5 \\
\mathrm{~cm}\end{array}$ & Incıdental & Lobectomy & $\begin{array}{l}\text { Moran, et al. } \\
2006\end{array}$ \\
\hline 57/male & Right upper lobe & $2 \mathrm{~cm}$ & Incidental & Lobectomy & $\begin{array}{l}\text { Moran, et al. } \\
2006\end{array}$ \\
\hline 58/female & Left upper lobe & $2 \mathrm{~cm}$ & Productive cough & Lobectomy & Moran, et al.2006 \\
\hline 69/female & Left lower lobe & $2 \mathrm{~cm}$ & Incidental & Lobectomy & $\begin{array}{l}\text { Moran, et al. } \\
2006\end{array}$ \\
\hline 22/female & Right lower lobe & $2 \mathrm{~cm}$ & Incidental & Lobectomy & $\begin{array}{l}\text { Carretta, et al. } \\
2004\end{array}$ \\
\hline 56/female & Right middle lobe & $2 \mathrm{~cm}$ & Incidental & Lobectomy & $\begin{array}{l}\text { Ang KL, et al. } \\
2003\end{array}$ \\
\hline 25/female & Left lung periphery & $\begin{array}{l}2.5 \\
\mathrm{~cm}\end{array}$ & Incidental & $\begin{array}{l}\text { Wedge resection/ } \\
\text { VATS }\end{array}$ & $\begin{array}{l}\text { Jin HY, et al. } \\
2007\end{array}$ \\
\hline 38/male & Right lobe & $\begin{array}{l}10 \\
\mathrm{~cm}\end{array}$ & $\begin{array}{l}\text { Post-traumatic after bull injury to } \\
\text { the chest }\end{array}$ & Surgical excision & $\begin{array}{l}\text { Pozgain, et al. } \\
2016\end{array}$ \\
\hline 67/female & Right middle lobe & NA & Incidental & Lobectomy & $\begin{array}{l}\text { Noda M, et al. } \\
2002\end{array}$ \\
\hline 36/male & Left lower lobe & NA & Incidental & Lobectomy & $\begin{array}{l}\text { Wang JS, et al. } \\
1994\end{array}$ \\
\hline 18/female & Right middle lobe & NA & Incidental & Lobectomy & $\begin{array}{l}\text { Tanigaki T, et al. } \\
2002\end{array}$ \\
\hline
\end{tabular}

TABLE 1: The case reports of benign primary pleomorphic adenomas of the lungs

The current world health organization (WHO) classification of lung tumors includes three malignant salivary gland-type tumors: adenoid cystic carcinoma, mucoepidermoid carcinoma, and epithelial-myoepithelial carcinoma. The two benign salivary gland-type tumors are the mucous gland adenomas and pleomorphic adenomas [10]. The latter can arise in the center or periphery of the lung and can grow in size up to $10 \mathrm{~cm}$ as reported by Pozgain, et al [5].

Macroscopically, PAs are polypoid tumours; they have a rubbery consistency, are often encapsulated and can have a myxoid or cartilaginous appearance. Histologically, they are described as mixed tumors and are characterized by biphasic cellular glandular components, mainly epithelial ducts and/or tubules which are embedded in a chondromyxoid stroma [10]. 
Most PAs are benign and rarely undergo malignant transformation. Features of malignant variants include cellular atypia, frequent mitotic figures, and necrosis. Our patient's PA did not have any malignant features. A physical examination of the salivary glands was conducted in our patient to rule out a metastatic origin of the lung PA.

The clinical presentation of PAs varies depending on the location of the tumour. Endobronchial tumours which arise from the epithelium of sub-mucosal bronchial glands are usually associated with cough, hemoptysis and shortness of breath. Peripheral tumours can sometimes present with fever, weight loss and pleural effusions. Nonetheless, the majority of cases are asymptomatic [7]. In fact, our patient denied any respiratory symptoms.

Little is known about the best treatment options for these exceedingly rare lung neoplasms; however surgical resection remains the most common approach as these tumours have the potential of malignant transformation. Our patient is scheduled for a follow-up visit to discuss surgical resection and interval surveillance.

\section{Conclusions}

In conclusion, primary benign pleomorphic adenomas of the lung are rare tumors of which the majority are asymptomatic and are incidentally discovered. In evaluating patients with pulmonary PAs, metastatic lesions from mixed tumors of the salivary glands and other biphasic pulmonary neoplasms such as blastoma, hamartochondroma, and carcinosarcoma should be considered in the differential diagnosis. Surgical resection is the treatment of choice for PA. Long-term surveillance is warranted due to the concerns for malignant transformation and recurrence of the disease.

\section{Additional Information}

\section{Disclosures}

Human subjects: Consent was obtained by all participants in this study. Conflicts of interest: In compliance with the ICMJE uniform disclosure form, all authors declare the following:

Payment/services info: All authors have declared that no financial support was received from any organization for the submitted work. Financial relationships: All authors have declared that they have no financial relationships at present or within the previous three years with any organizations that might have an interest in the submitted work. Other relationships: All authors have declared that there are no other relationships or activities that could appear to have influenced the submitted work.

\section{References}

1. Ang KL, Dhannapuneni VR, Morgan WE, et al.: Primary pulmonary pleomorphic adenoma: an immunohistochemical study and review of the literature. Arch Pathol Lab Med. 2003, 127(5):621-622.

2. Moran CA, Suster S, Askin FB, et al. : Benign and malignant salivary gland-type mixed tumors of the lung: clinicopathologic and immunohistochemical study of eight cases. Cancer. 1994, 73(10):2481-2490. 10.1002/1097-0142(19940515)73:10<2481::AIDCNCR2820731006>3.0.CO;2-A

3. Carretta A, Libretti L, Taccagni G, et al. : Salivary gland-type mixed tumor (pleomorphic adenoma) of the lung. Interact CardioVasc Thorac Surg. 2004, 3(4):663-665. 10.1016/j.icvts.2004.07.017

4. Jin HY, Park TS: Pulmonary pleomorphic adenoma: a report of a rare case . Korean J Intern Med . 2007, 22(2):122-124. 10.3904/kjim.2007.22.2.122

5. Pozgain Z, Dulic G, Kristek J, et al.: Giant primary pleomorphic adenoma of the lung presenting as a post-traumatic pulmonary hematoma: a case report. J Cardiothorac Surg. 2016, 


\section{Cureus}

11:18. 10.1186/s13019-016-0409-Z

6. Noda M, Tabata T, Yamane Y: Pleomorphic adenoma of the lung: report of a case . Europe PMC. 2002, 55(12):1073-1076.

7. Wang JS, Tseng CH: Pleomorphic adenoma of the lung-report of a case and review if the literature. Gaoxiong Yi Xue Ke Xue Za Zhi. 1994, 10(9):522-527.

8. Tanigaki T, Shoyama Y, Iwasaki M, et al.: Pleomorphic adenoma in the lung. Monaldi Arch Chest Dis. 2002, 57(1):30-32.

9. Zarbo RJ: Salivary gland neoplasia: a review for the practicing pathologist . Mod Pathol. 2002, 15(3):298-323. 10.1038/modpathol.3880525

10. Klijanienko J, Servois V, Jammet P, et al.: Pleomorphic adenoma. Am J Surg Pathol. 1998, 22(6):772-773. 